\title{
Khotbah Yang Berwawasan Misiologis
}

\author{
Johana Ruadjanna Tangirerung \\ Universitas Kristen Indonesia Toraja \\ jrtangirerung@ukitoraja.ac.id
}

\section{DOI: https://doi.org/10.34307/b.v4i2.259}

\begin{abstract}
A church is then called a church if it carries out a mission. Preaching is part of the mission of the church. Preaching in the context of Christianity is a form of verbal preaching of the gospel. The Protestant Church places preaching at the center of worship. The strategic position of this sermon can be the starting point for a missiological sermon. Even though the sermon is the center of worship and one of the models of preaching the gospel, but whether these sermons have a missiological perspective. The purpose of this study is to describe the basis of the sermon which is called missiological insight. Another goal is that through this descriptive description, the church understands further the mission of the church in preaching the gospel and then becomes an evaluative starting point for present-day church sermons towards missionary-minded sermons towards missionary congregations. This study uses a descriptive qualitative approach, which relies on efforts to describe and describe the phenomenon of contemporary sermons to be confronted with the reality of the sermons offered, namely sermons with a missiological perspective. This research shows that preaching the gospel through preaching is a means of preaching the gospel and it is part of the church's mission and churches need to develop missiologicalminded preaching for church growth. A sermon with a missiological perspective is a sermon that can direct and move all elements of the congregation to be involved in carrying out God's mission as a result of these sermons in the context of church growth.
\end{abstract}

Keywords: sermons, preaching the gospel, church missions, missionary sermons

Abstrak: Gereja barulah disebut gereja jika melakukan misi. Berkhotbah adalah bagian dari misi gereja. Khotbah dalam konteks kekristenan adalah salah satu bentuk pemberitaan Injil secara verbal. Gereja Protestan menempatkan khotbah sebagai pusat ibadah. Posisi strategis khotbah inilah yang dapat menjadi titik berangkat khotbah yang misiologis. Sekalipun khotbah adalah pusat ibadah dan salah satu model pemberitaan Injil, akan tetapi apakah khotbah-khotbah tersebut sudah berwawasan misiologis. Tujuan penelitian ini adalah mendeskripsikan pendasaran khotbah yang disebut berwawasan misiologis. Tujuan lain adalah melalui uraian deskriptive ini gereja memahami lebih jauh misi gereja dalam pemberitaan Injil lalu menjadi titik berangkat evaluatif terhadap khotbah-khotbah gereja masa kini menuju khotbah yang berwawasan misiologis. Penelitian ini menggunakan metode pendekatan descriptive qualititavie, yang bertumpu pada upaya menguraikan dan mendeskripsikan fenomena khotbah-khotbah masa kini untuk diperhadapkan pada realitas khotbah yang ditawarkan yaitu khotbah yang berwawasan misiologis. Penelitian ini memperlihatkan bahwa pemberitaan Injil melalui khotbah adalah sarana pemberitaan Injil dan itu adalah bagian dari misi gereja dan gereja-gereja perlu untuk mengembangkan khotbah yang berwawasan misiologis untuk pertumbuhan gereja. Khotbah yang berwawasan misiologis adalah khotbah yang dapat mengarahkan dan menggerakkan seluruh elemen jemaat untuk terlibat dalam 
pelaksanaan misi Allah sebagai dampak dari khotbah-khotbah tersebut dalam rangka pertumbuhan gereja.

Kata Kunci: khotbah, pemberitaan Injil, misi gereja, khotbah yang berwawasan misiologis

\begin{tabular}{llll}
\hline Article History : & Received: 21-05-2021 & Revised: 28-09-2021 Accepted: 28-09-2021
\end{tabular}

\section{Pendahuluan}

Gereja ada karena misi sehingga gereja barulah menjadi gereja yang hakiki jika gereja melaksanakan misi. ${ }^{1}$ Gereja sebagai instrumen misi Allah (missio ecclesiae) mengemban tugas dari Allah (missio Dei dan missio Christiae) dalam melakukan misi. ${ }^{2}$ Namun dalam tataran praksis, misi sebagai DNA gereja belum 'menubuh' sebagaimana makna, hakikat serta praktik misi seperti yang dimaksud di atas. Akibatnya misi gereja belum dikerjakan dengan maksimal, gereja seringkali terlalu berfokus kepada kegiatan-kegiatan internal, dan kegiatan misi dan pelaksananya oleh orang-orang tertentu atau departemen tertentu di dalam gereja. Program-program misi lebih pada upaya menjangkau suku-suku terasing dan agama-agama lain untuk dikristenkan, sebagaimana pola dan praktik misi Barat, dan kegiatan-kegitan lain yang bersifat romantisisme misalnya dalam kegiatan-kegiatan yang gereja sebut mission trip, mission in the field, dan lain-lain. Hal ini disebabkan karena paham dan praktek-praktek misi yang beragam. ${ }^{3}$ Pertanyaannya, sejauh mana esensi misi gereja dapat dilakukan dan dimaknai pada praktek misi gereja sebagai DNA gereja dan dengan demikian menubuh dalam seluruh kegiatan bergereja atau bermisi? Atas dasar itu maka perlu pemahaman yang komprehensif dan kontekstual mengenai misi gereja dan bagaimana wujudnya dalam praktek bergereja atau bermisi. Salah satu kegiatan bergereja adalah berkhotbah dalam ibadah-ibadah. Berkhotbah atau memberitakan Injil dalam ibadah kristiani merupakan sentral dan merupakan kegiatan misi. Bahkan dengan mengutip pernyataan Rasul Paulus, “Celakalah aku jika tidak memberitakan Injil”, Ibelala Gea dalam artikelnya menegaskan bahwa, orang yang sudah diselamatkan di dalam Kristus memiliki tugas mutlak dan kewajiban untuk memberitakan Injil. ${ }^{4}$ Hal yang sama dikatakan Kalis Stevanus, bahwa yang menjadi dasar dari seluruh pekabaran Injil adalah karya Kristus dalam kematian dan kebangkitan-Nya. ${ }^{5}$ Dari uraian di atas dapat dikatakan bahwa pemberitaan Firman dalam ibadah menjadi pusat penyemaian Firman Tuhan

\footnotetext{
1 Widi Artanto, Menjadi Gereja Misioner dalam Konteks Indonesia (BPK Gunung Mulia- Kanisius, 1997), 29.

2 J. Bosch David, Transformasi Misi Kristen:Sejarah Teologi Misi Yang Mengubah Dan Berubah, 11th ed. (Jakarta: BPK Gunung Mulia, n.d.), 15, 568, 598, 599, 758.

3 Widi Artanto, Menjadi Gereja yang Misioner, 26-31.

${ }^{4}$ Ibelala Gea, "Beritakan Injil Kepada Segala Makhluk," BIA': Jurnal Teologi dan Pendidikan Kristen Kontekstual 1, no. 1 (30 Juni 2018): 56-69.

${ }^{5}$ Kalis Stevanus, "Karya Kristus Sebagai Dasar Penginjilan di Dunia Non-Kristen," Fidei: Jurnal Teologi Sistematika dan Praktika 3 No.1 (June 2020): 1-19.
} 
melalui khotbah, dan ini tanggungjawab gereja dalam pelaksanaannya sebagai bagian misi.

Gereja mengungkapkan imannya melalui ibadah. Ibadah atau misa (Katolik) berpuncak pada perayaan Ekaristi (perjamuan), khotbah atau homili merupakan pelengkap saja. Setelah Reformasi, khusunya Calvin, meletakkan homili atau khotbah (pewartaan, pemberitaan Firman) menjadi pusat Ibadah. ${ }^{6}$ Simbol bahwa khotbah tersebut merupakan inti atau pusat dari kebaktian ialah mimbar. Mimbar sebagai tempat pemberitaan Firman dalam landscape tata letak ruang ibadah, diletakkan di tengah altar gereja. Menjadi jelas bahwa khotbah sebagai pemberitaan firman merupakan pusat dari ibadah-ibadah atau kebaktian gereja. Pentingnya khotbah sehingga menjadi sentral dalam ibadah jemaat dan berpengaruh pada pertumbuhan iman jemaat, dikemukakan oleh Marsi Bombongan Rantesalu. Hasil penelitiannya menunjukkan bahwa khotbah berpengaruh $53,2 \%$ terhadap jumlah peserta ibadah, berpengaruh $72,4 \%$ terhadap pertumbuhan secara kualitatif, dan $47,3 \%$ bagi pertumbuhan keorganisasian gereja. ${ }^{7}$ Penelitian senada dari Wellem Sairwona mengemukakan bahwa khotbah sebagai sarana pemberitaan Firman Allah memiliki hubungan yang sangat kuat terhadap persekutuan jemaat dan pertumbuhan iman jemaat. Hubungan tersebut sangat logis, spiritual dan melampaui keadaan manusia atau bersifat adikodrati sehingga berdampak langsung terhadap pertumbuhan iman warga jemaat. ${ }^{8}$ Penelitian terhadap khotbah sebagai sentral sehingga perlu dipikirkan pentingnya penyampaian khotbah diperhatikan, dikemukakan oleh Yovianus Epan dan Paulus Purwoto. Penelitian itu mengemukakan perlunya metode penyampaian firman dalam konteks dan tantangan era revolusi industri 4.0. Pemberitaan Firman mesti dapat memanfaatkan kemajuan teknologi informasi dan media komunikasi melalui sosial media bagi sebagian besar generasi muda yang melek teknologi. ${ }^{9}$

Penelitian-penelitian di atas memperlihatkan pentingnya dan bagaimana letak strategis khotbah ini menjadi sangat penting untuk diperhatikan baik terkait isi khotbah, metode, dan penyampaiannya. Akhir-akhir ini khotbah sifatnya lebih popular, maksudnya yang penting khotbah-khotbah tersebut enak didengar dan disukai orang, lalu abai memberi penekanan pada apakah khotbah-khotbah tersebut dapat berdampak misiologis. Apalagi dengan semakin majunya teknologi komunikasi, maka khotbahkhotbah terebut dapat dilakukan dan disimak melalui media komunikasi seperti youtube. Malahan pada masa pandemi covid-19, gereja-gereja melakukan ibadah live streaming,

${ }^{6}$ Christian de Jonge, Apa Itu Calvinisme? (BPK Gunung Mulia, 2000), 165-179.

${ }^{7}$ Rantesalu Marsi Bombongan and Suswati Duapadang, “Analisis Tentang Pengaruh Khotbah Bagi Pertumbuhan Gereja Masa Kini,” Integritas:Jurnal Teologi 3, Nomor 1 (June 2021): 240-255.

8 Wellem Sairwona, "Kajian Teologis Penyampaian Firman Tuhan dan Pengaruhnya bagi Pertumbuhan Iman Jemaat”, Shanan:Jurnal Pendidikan Agama Kristen 1 No 1( Oktober 2017): 131.

${ }^{9}$ Yovianus Epan and Paulus Purwato, "Metode Pemberitaan Kabar Baik Tuhan Yesus Dalam Matius 4:23-25 Dan Aplikasinya Bagi Pemberitaan Kabar Baik," Miktab: Jurnal Teologi dan Pelayanan Kristiani 1 No.1 (June 2021): 1-27. 
jadi ibadah minggu juga dapat diikuti secara virtual. Namun semua penelitian di atas belum memperlihatkan bahwa khotbah mestinya dapat menjadi kesempatan untuk menjadikan khotbah sebagai kegiatan misiologis. Pada posisi inilah pentingnya penelitian ini. Gereja yang kreatif adalah yang tanggap pada situasi, khususnya dalam konteks dunia modern di mana teknologi komunikasi sudah memudahkan setiap orang untuk mendengar khotbah, selain khotbah-khotbah yang dilakukan di dalam gereja. Memang gereja perlu menelisik, sejauh mana khotbah-khotbah yang dilakukan secara meluas itu dapat dipertanggung-jawabkan isi, dogma dan teologianya. Sebab seluruh proposal misiologis selalu diletakkan di atas dasar teologi yang sahih.

Meskipun khotbah-khotbah menempati posisi strategis dalam ibadah sebagai media pekabaran Injil dan sudah semakin berkembang serta beragam metode penyampaian, namun apakah khotbah-khotbah tersebut berwawasan misiologis? Atas dasar statemen tesis tersebutlah penulis ingin menguraikan landasan teologis khotbah yang berwawasan misiologis. Tujuan penelitian ini adalah tersedianya pendasaran teologis khotbah yang disebut berwawasan misiologis; kedua, gereja memahami lebih jauh memberitakan Firman sebagai bagian dari misi gereja dalam pemberitaan Injil lalu menjadi titik berangkat yang dapat mengevaluasi khotbah-khotbah gereja masa kini menuju khotbah yang berwawasan misiologis sebagai jemaat yang missioner. Posisi sentral pemberitaan firman inilah yang mendorong penulis melakukan penelitian yaitu bagaimana khotbah atau pemberitaan Firman itu berwawasan misiologis.

\section{Metode Penelitian}

Metode penelitian ini menggunakan penelitian deskriptif kualitatif dengan memaparkan realitas misi dan khotbah. Penekanan metode penelitian ini adalah deskripsi dan analisis fenomena khotbah yang ada dan yang ditawarkan yaitu khotbah yang berperspektif misiologis. ${ }^{10}$ Berangkat dari sini, maka sejatinya upaya ini merupakan upaya mendulang pemahaman misiologis yang utuh, untuk selanjutnya menjadi pendasaran dalam mengajukan khotbah-khotbah Kristen berwawasan misiologis. Pemahaman misiologis berdasarkan para pakar khususnya misiolog seperti Kuyper, Bosch, Bevans, Edmun Woga, dan Widi Artanto, yang dikemukakan pendapat dan pemahamannya dalam penelitian ini, juga beberapa landasan teologis tentang pemberitaan Firman akan mendriving penelitian ini menuju deklarasi misilogis bahwa khotbah merupakan kegiatan misi, sehingga khotbah-khotbah Kristiani selayaknya dipersiapkan secara bersengaja menjadi khotbah-khotbah yang berwawasan misiologi.

\section{Hasil dan Pembahasan}

\section{Beberapa Landasan Memahami Misi Gereja}

10 Wijsen Frans, Metode-Metode Penelitian Misiologis Frans Wijsen (Peter Lang, Bern, 2013). 
Pada tataran arti kata, kata misi dalam bahasa Inggris terdapat dua istilah yang berbeda pengertian, yakni mission dan missions. Kata missions diartikan sebagai pekerjaanpekerjaan spesifik yang dilakukan gereja dan lembaga gerejawi dalam melaksanakan tugas menjangkau orang-orang bagi Kristus melalui pelayanan lintas budaya. Sedangkan mission lebih luas, menunjukkan kepada segala sesuatu yang gereja lakukan yang mengarah kepada Kerajaan Allah. ${ }^{11}$ Dari pengertian terakhir ini yaitu istilah missions, penulisan ini akan berangkat menerjemahkan, bahwa khotbah-khotbah dapat juga diartikan sebagai kegiatan misi (missions), sehingga diharapkan khobtah-khotbah yang dilakukan oleh gereja adalah khotbah yang misiologis. Khotbah yang misiologis adalah khotbah yang menjadikan setiap orang yang telah mendengarkan kebenaran Firman kembali ke kehidupannya, atau menjadi utusan-utusan ke dalam dunia di mana ia berkarya menjadi pelaku-pelaku Firman.

Arie de Kuiper, misiolog terkemuka itu menyimpulkan uraiannya mengenai misi gereja. Kuiper mengatakan, "misi Gereja dalam sejarahnya dikenal dalam berbagai istilah misalnya: Missio Ecclesiae yang artinya pengutusan gereja yaitu pekerjaan missioner dari jemaat Kristen sepanjang sejarah dunia; Missio Apostolorum yaitu pengutusan para rasul; Missio Christiae, yaitu pengutusan Kristus dalam arti (a) Kristus diutus Allah dan (b) Kristus mengutus murid-muridNya, Band Yoh.20:21; Misio Dei, yaitu keseluruhan pekerjaan Allah untuk menyelamatkan dunia; mulai dari pemilihan Israel, pengutusan nabi kepada Israel dan kepada bangsa-bangsa sekitarnya, pengutusan Kristus kepada dunia, pengutusan rasul-rasul dan pekabar-pekabar Injil kepada bangsa-bangsa. Allah menjadi pengutus Agung."12

Tugas missioner gereja-gereja secara konvensional dapat dibagi ke dalam dua garis besar yaitu, misi ke dalam dan ke luar dan misi sebagai pengkristenan Pemahaman konvensional ini masih banyak hidup dalam gereja-gereja. Widi Artanto berdasarkaan pemaparan David J. Bosch dalam Transformasi Misi Kristen menegaskan lebih jauh cakupan misi dengan mengatakan bahwa, misi adalah sebuah upaya yang lebih komprehensif dan holistik. Misi tidak dapat dibandingkan dengan penginjilan. Lebih jelasnya Widi mengatakan:

"Misi lebih luas dari penginjilan. Penginjilan adalah misi, tetapi misi tidak hanya penginjilan. Misi adalah tugas total dari Allah yang mengutus gereja demi keselamatan dunia. Gereja diutus kedalam dunia untuk mengasihi, melayani, mengajar, menyembuhkan dan membebaskan. Penginjilan tidak dapat disamakan dengan misi karena ia merupakan bagian integral dari misi sehingga tidak dapat diisolasi menjadi aktivitas yang terpisah"13

11 Yosua Felciano Cemerlang and Hengki Wijaya, "Misi Dan Kebangkitan Rohani: Implikasi Misi Allah Bagi Gereja," Jurnal Ilmiah Religiosity Entity Humanity (JIREH) 1 No.1 (June 2019): 57-71.

12 Arie de Kuiper, Missiologia, 18 (BPK Gunung Mulia, 2010), 10.

13 Widi Artanto, Menjadi Gereja yang Misioner, 15. 
David J. Bosch menyarikan lebih lengkap beragam pemahaman yang muncul sepanjang sejarah misi yaitu, penyebaran iman, perluasan pemerintahan Allah, pertobatan orang-orang kafir, dan pendirian jemaat-jemaat baru. Rentang sejarah memperlihatkan bagaimana misi mengalami perkembangan pemahaman. Perubahan ini disebut oleh David J. Bosch "sift paradigm" atau pergeseran paradigm misi. Mulai dari pengirimin tenaga misionaris, kegiatan-kegiatannya, wilayahnya, pembagian dunia non Kristen dan Kristen, dan seterusnya. Semua hal itu mewarnai perjalanan pemahaman misi. Misi dipahami sebagai penyebaran iman dan perluasan wilayah (Kerajaan Allah) sampai pada pertobatan orang-orang kafir dan pendirian jemaat-jemaat baru. Barulah pada abad ke-16 pemahaman ini mengalami penekanan biblis yang mengacu pada pola Tritunggal yaitu, pengutusan Anak oleh Bapa dan pengutusan Roh Kudus oleh Bapa dan Anak. ${ }^{14}$

Mungkin timbul pertanyaan, mengapa begitu banyak istilah yang digunakan untuk 'misi'? Beragamnya pemahaman ini oleh karena ada begitu banyak perbedaan motivasi dalam pengertian misi yang mempunyai akibat pada karya perutusan itu sendiri. Motivasi-motivasi itu misalnya: (1) motivasi tradisional seperti pertobatan, penyelamatan jiwa-jiwa, penanaman gereja di tengah-tengah bangsa non Kristen; (2) motivasi kekuasaan dalam bentuk penguasaan wilayah-wilayah; (3) motivasi suci, sebagai pengutusan Kristus oleh Allah ke tengah-tengah dunia. ${ }^{15}$. Pemahaman ini berubah searah perubahan di mana konteks misi itu berada dan khusunya refleksi gereja terhadap konteksnya sebagai upaya berteologi.

Motivasi-motivasi itu dilatarbelakangi oleh paradigm misi tertentu. Paradigma misi adalah pandangan misi yang muncul dari masa dan konteks tertentu di mana gereja hadir. Bosch mengemukakan paradigm misi yang berkembang sepanjang sejarah misi itu seperti: (1) Paradigma misi masa PL dan PB, di dalamnya masih terbagi pada masa dan konteks kitab tertentu, mialnya paradigm misi Matius dan Lukas tentu ada perbedaan, juga misalnya paradigma misi Paulus; (2) Paradigma misi gereja perdana; (3) Paradigma misi masa Bapa Gereja; (4) paradigm misi masa Abad Pertengahan; (5) Paradigma misi Gereja Ortodoks Timur (6) paradigm misi gereja Katolik Roma; (7) Paradigma Misi Reformasi; (8) Paradigma misi masa Pencerahan dan (9) Paradigma misi ekumenis yang sedang muncul. ${ }^{16}$ Paradigm-paradigma inilah yang memengaruhi praktek-praktek misi di lapangan misi.

Pada zaman ekumenis paradigma misi mulai berubah, yang pada awalnya sangat berpusat pada gereja, menempatkan gereja sebagi tujuan misi bahkan dalam sejarah seringkali menempatkan diri sebagai sumber dan tujuan misi. Pendasaran lain yang muncul pada dekade akhir sebagai paradigm misi ekumenis ialah paradigm misi yang

14 Ibid., 285-295.

${ }^{15}$ David, Transformasi Misi Kristen:Sejarah Teologi Misi Yang Mengubah Dan Berubah, 1.

${ }^{16}$ Ibid., 567-756. 
mulai meletakkan kembali pemahaman gereja sebagai alat atau utusan yang tujuannya atau objeknya adalah dunia. Persoalan-persoalan yang menjadi konsern misi adalah dunia yang terkait dengan sosal-soal sosial, budaya dan anthropologi. Unsur-unsur paradigma misi yang mengemuka pada masa paradigm misi ekumenis sebgaimana diuraiakan Bosch antara lain, misi sebagai gereja dengan yang lainnya, misi sebagai perjuangan keadilan, misi sebagai kontekstualisasi, misi sebagai pembebasan, misi sebagai inkulturisasi, misi sebgai kesaksian bersama, misi sebagai pelayanan seluruh umat, Allah, dan misi sebagai kesaksian kepada orang-orang berkepercayaan lain. ${ }^{17}$

Sementara itu, Stevens Bevans dan Roger Schroeder khususnya ketika berbicara mengenai perkembangan pemahaman dan praktek misi dalam gereja protestan mengemukakan beberapa penekanan misalnya misi sebagai pewartaan dan pertumbuhan gereja, misi sebagai upaya mewujudkan keutuhan ciptaan, kemajemukan/pluralitas, dan misi sebagai pembebasan seluruh umat dan misi sebagai dialog profetis, perempuan dan misi serta misi sebagai pewartaan tentang Yesus Kristus sebgai penyelamt universal.18 Model dan pendekatan baru ini menantang gereja melakukan upaya-upaya misiologis yang kreatif, tidak terbatas pada upaya-upaya konvensional. Model dan metode misi sebagai pewartaan atau pemberitaan Firman atau khotbah menjadi dasar misiologisnya. Penelitian ini akan melihat lebih jauh apa dan bagaimana khotbah yang berwawasan misiologis itu sebagai dasar untuk meningkatkan pertumbuhan gereja.

\section{Khotbah sebagai Sarana Pekabaran Injil}

Pemberitaan Firman dalam gereja pada umumnya dikenal dalam dua bentuk yaitu pemberitaan Firman yang kelihatan, yang bersifat verbal dan kesaksian. Pemberitaan Firman yang kelihatan melalui Sakramen Baptisan dan Perjamuan Kudus. Sementara pemberitaan Firman yang bersifat verbal atau yang diucapkan dengan kata-kata, ialah berkhotbah dan kesaksian hidup adalah melalui kehidupan sehari-hari. Jadi khotbah atau berkhotbah merupakan salah satu bagian dari pemberitaan Firman.

Berkhotbah adalah bagian dari misi yaitu Pekabaran Injil, jadi berkhotbah berarti bermisi dengan cara mengabarkan Injil melalui kata-kata. Namun berkhotbah bukan juga sekedar kata-kata indah, sebagaimana dikatakan oleh Beny Solihin, dalam kutipan di bawah ini:

"khotbah bukanlah suatu permaian kata-kata yang indah atau menyenangkan hati pendengar saja. Khotbah itu adalah mempunyai dasar yang hakiki, dasar yang fundamental yaitu Alkitab (firman Tuhan). Khotbah bukan penemuan manusia, tetapi

17 Ibid., 565-765.

18 Stephen B Bevans and Roger P Schroeder, Terus Berubah Tetap Setia: Dasar, Pola, Konteks Misi (Ledalero, 2006), 596. 
kreasi Tuhan, hanya kuasa Roh Kudus yang dapat mengubahmanusia, Alkitab sebagai dasar khotbah diinspirasikan dan diiluminasikan oleh Roh Kudus"19

Berkhotbah merupakan sebuah kegiatan menyampaikan kehendak Allah kepada umat secara verbal berdasarkan Alkitab. Berkhotbah juga dapat dilakukan dengan berbagai cara dan metode. Melalui berkhotbah, jemaat dapat dihibur, dikuatkan dan diteguhkan ketika menghadapi berbagai pergumulan; melalui khotbah jemaat dapat diingatakan untuk selalu bersyukur atas segala penyertaan dan suka cita.

Khotbah-khotbah yang disampaikan dalam jemaat seyogianya bermura dan berdampak misiologis. Artinya, khotbah itu mestinya menggerakkan pengkhotbah dan jemaat atau pendengar untuk melakukannya di dalam dunia sebagaimana Calvin sebut sebagai teathron gloria Dei, dunia menjadi panggung kemuliaan Allah. ${ }^{20}$ Jadi berkhotbah mesti dilakukan dalam kesadaran misiologis yang digerakkan oleh Allah Tritunggal, sehingga menjadi sarana penyamapaian kehendak Allah agar manusia menyatakan seluruh kehendak Allah itu di dalam dunia.

Pelayanan gereja dalam semangat reformasi khususnya Calvin sudah menempatkan khotbah sebagai inti dari setiap ibadah. Meskipun demikian perlu dihindari untuk memisahkan satu unsur atau akta ibadah satu dengan yang lainnya sebagai sesuatu yang terpisah. Khotbah menjadi inti dari setiap ibadah dan dianggap sebagai kesempatan untuk memberitakan Firman yang akan menjadi penghiburan, penguatan dan peneguhan bagi warga jemaat, gereja-gerejapun memberi perhatian khusus pada kegiatan berkhotbah. Pentingnya khotbah sebagai sarana pekabaran Injil yang misiologis dapat dilihat dalam Roma 10:14: “...Bagaimana mereka dapat percaya kepada Dia, jika mereka tidak mendengar tentang Dia...." Selanjutnya masih dalam kitab yang sama yaitu Roma 10:17 di sana dikatakan: "Jadi, iman timbul dari pendengaran, dan pendengaran oleh firman Kristus." Menjadi jelas bahwa iman dapat berasal dan tumbuh salah satunya melalui pemberitaan Firman.

Bingkai Sola Scriptura reformatoris, menjadi titik berangkat dari upaya menjadikan khotbah sebagai lokus misiologis pemberitaan Firman. Sebagai wahana pemberitaan Firman, maka ia harus diletakkan pada posisi otoritas eksklusif, maka tepatlah apa yang Paulus sampaikan bahwa pemberitaan Firman Tuhan itu adalah perintah yang wajib dan mutlak dilakukan. Perintah ini disampaikan kepada Timotius anak rohaninya: "Siap sedialah, beritakanlah Firman baik atau tidak baik waktunya, nyatakanlah apa yang salah, tegorlah dan nasihatilah dengan segala kesabaran dan pengajaran" (1 Timotius 4:2).21 Dalam bingkai ini pemberitaan Firman atau berkhotbah

19 Benny Solihin, 7 Langkah Menyusun Khotbah Yang Mengubah Kehidupan (SAAT Malang, 2014), 33.

20 Jonge, Apa Itu Calvinisme?, 55.

21 Iskandar Santoso, "Khotbah Yang Berkuasa, Suatu Tinjauan Praktis," Aletheia 4 No.6 (March 2002): 43-61. 
menjadi kegiatan yang sangat teologis sebagai sarana menyampaiakan kehendak Allah, menegur dan menasihati.

\section{Khotbah Gereja Masa Kini}

Menyadari pentingnya berkhotbah sebagai sarana pekabaran Injil, gereja kemudian melakukan berbagai pelatihan agar pengkhotbah-pengkhotbah dapat membawakan khotbah dengan baik dan menarik. Hal ini sudah dirasakan hamper di seluruh gerejagereja dengan terlihatnya peningkatan kualitas dan cara berkhotbah. Dari sisi lain realitas, ciri, bentuk dan isi serta tujuan khotbah sangat beragam. Hal itu menjadi bukti bahwa khotbah telah menjadi perhatian penting gereja. ${ }^{22}$ Meskipun gereja-gereja sudah melihat khotbah sebagai sesuatu yang penting, namun perlu pemahaman tentang khotbah yang berwawasan misiologis.

Konteks dunia saat ini tentu menjadi indikator bagaimana khotbah itu disampaikan, baik konten maupun penyampaiannya. Tak ayal lagi dibutuhkan persiapan yang sungguh terkait dengan isi khotbah dan kesiapan rohani si pengkhotbah sendiri, karena khotbah tanpa hati yang dipenuhi Roh Kudus, sama halnya dengan berpidato atau berorasi. Salah satu indikator khotbah yang baik adalah membawa pertumbuhan jemaat dalam hal kualitas dan kuantitas. ${ }^{23}$ Namun pada kenyataannya khotbah-khotbah masa kini bersifat eksemplaris bahkan cenderung menjadi ruang entertain. ${ }^{24}$

Pengamatan terhadap beberapa khotbah masa kini baik melalui mimbar gereja ${ }^{25}$ maupun mimbar gereja online terlihat bahwa pengkhotbah sudah lebih sadar memperhatikan kebutuhan jemaat akan siraman rohani. ${ }^{26}$ Gereja semakin sadar bahwa cara membawakan khotbah atau menampilkan menu menjadi perhatian serius. Glorius Bawengan meyadari akan realitas tersebut, membuat pelatihan dan penerbitan buku berjudul "Khobah Multikreatif" sebagai jawaban atas kebutuhan jemaat akan khotbah yang tidak membosankan. ${ }^{27}$ Demikian juga Benny Solihin ${ }^{28}$ yang dalam bukunya mengemukakan bagaimana pentingnya mempersiapkan khotbah dengan baik. Hal itu karena konteks dunia saat ini memperlihatkan berbagai tekanan atas kehidupan umat.

22 Dwi Setio Budiono Santoso, "Peran Khotbah Gembala Sidang Dalam Pertumbuhan Rohani Jemaat," Magnum Opus: Jurnal Teologidan Kepemimpinan Kristen 1 No.2 (June 2020): 88-97.

23 Stevan Paas, "A Case Study of Church Growth by Church Planting in Germany: Are They Connected?," Sage Journal 42, No. 1. (2018), https://journals.sagepub.com/doi/10.1177/ 2396939317738896.

24 Mark Applegate, "Differences Between Non-Denominational \& Baptist Churches," Biz Fluent, Agustus 2018, https://bizfluent.com/12083238/differences-between-non-denominational-baptistchurches. (2019).

25 Tiara Asrilita, "Pengaruh Pengkhotbah Tamu Dalam Pertumbuhan Iman Di JKI Imanuel Kudus”

${ }^{26}$ Hansamena Wau, "Hukum Utama Dalam Mempersiapkan Khotbah," Kerusso, Jurnal Teologi dan Pelayanan 6 No.1 (March 2021): 19-34.

27 Glorius Bawengan, Komet: Khobtah Multikreatif, 2018.

28 Solihin, 7 Langkah Menyusun Khotbah Yang Mengubah Kehidupan. 
Pada konteks inilah sesungguhnya khotbah-khotbah mestinya mendorong setiap orang yang mendengar khotbah terdorong bahwa anugerah itu tidak berhenti pada diri sendiri ketika Firman itu tiba, tetapi diteruskan sebagai tugas misiologis. Hal ini jugalah yang dimaksud oleh Myles Munroe dalam Wellem Sairwona ketika menyoal landasan teologis misiologis khotbah yang membuat umat sejatinya terus melakukan pekabaran Injil melalui kesaksian profetis mengatakan, "Temukanlah apa yang seharusnya engkau lakukan, dan sajikanlah itu kepada orang lain. ${ }^{29}$ Pemberitaan Firman tidak berhenti di gedung-gedung gereja tetapi meneruskan Firman itu kepada orang lain.

Sebuah survey yang dilakukan oleh mahasiswa STT Jakarta dalam tugas homiletika mengenai pemberitaan firman di jemaat-jemaat, ${ }^{30}$ mengemukakan pertanyaan tentang harapan setelah mendengarkan khotbah, memberikan jawaban jawabannya sebagai berikut: (1) aplikatif, aktual, sesuai dengan kehidupan sehari-hari yang kita hadapi; (2) Firman yang disampaikan mudah dipahami dan tidak bertele-tele; (3) Membangkitkan pengharapan, optimisme, pemghiburan, sebagai bahan evaluasi diri, dan memberi motivasi untuk tujuan hidup; (4) menjadi pedoman hidup; (5) Bisa menggerakkan orang yang mendengar untuk melakukan Firman. ${ }^{31}$ Dari salah satu pertanyaan survey tersebut, poin 1-5 mengharapkan khotbah itu dapat dipahami dengan mudah dan merupakan sarana menguatkan, menghibur dan meneguhkan serta reflektif bagi si pendengar khobtah. Hanya poin 5 yang dapat menunjukkan bahwa khotbah diharapkan sebagai wahana misiologis profetis. Survey ini dapat menjadi petunjuk untuk mengatakan bahwa khotbah-khotbah masa kini masih kurang memberi porsi penekanan pada unsur misiologisnya.

\section{Khotbah yang Berwawasan Misiologis}

Bevans dan Scrhoeter mengemukakan enam komponen Hakiki dari misi Allah di mana gereja dipanggil untuk ambil bagian yaitu: (1) kesaksian dan pewartaan; (2) Liturgi, doa dan kontemplasi; (3) komitmen kepada keadilan; (4) praktik dialog antar agama; (5) upaya-upaya inkulturasi, dan (6) pelayanan rekonsiliasi. ${ }^{32}$ Bahwa semua hal yang dikemukakan Bevans dam Scrhoeter dapat bermakna misi namun yang penulis maksudkan sejak awal penulisan ini, spesifik pada kesaksian dan pewartaan. Pewartaan dan kesaksian adalah dua hal dalam misi dapat disebut sebagai dua sisi mata uang yang tidak dapat dipisahkan dan merupakan inti tugas gereja, itulah sebabnya gereja melakukan pemberitaan Firman. Bahkan Paus Paulus VI pernah berkata, "sarana utama bagi evangelisasi adalah kesaksian hidup Kristen autentik". ${ }^{33}$ Meskipun Evangelisasi di

29 Wellem Sairwona, "Kajian Teologis Penyampaian Firman Tuhan dan Pengaruhnya bagi Pertumbuhan Iman Jemaat" Shanan: Jurnal Pendidikan Kristen 1 No.2 (Oktober 2017):116-131.

30 Survey ini dilakukan oleh Kelas Latihan Khotbah II STT Jakarta pernah melakukan sebuah penelitian kecil mengenai 'Pemberitaan Firman di Jemaat', tahun 2017.

31 Gerry Atje, "Pemberitaan Firman Di Jemaat" (Survey presented at the Survey, Jakarta, 2007).

32 Bevans ,Terus Berubah-Tetap Setia: Dasar, Pola, Konteks Misi, 596.

33 Ibid, 597. 
kalangan Injili dan pentakostal pada awalnya dipahami dalam bingkai khotbah dan pengutusan, namun pada kalangan mainstream dan Katolik dipahami sebagai pewartaan dan kesaksian yang mesti dinyatakan dalam kehidupan nyata. Dalam buku yang lain Bevans dan Schroeter mengemukakan arah baru di dalam misi dan evangelisasi ialah berujung pada kesaksian. Kesasksian adalah perkataan dan tindakan yang melahirkan panggilan dari setiap orang untuk merespons kasih dan anugerah Allah di dalam Kristus sebagai inti pemberitaan dan kesaksian tersebut. ${ }^{34}$ Ini menjadi indikasi yang penting bahwa pemberitaan Firman atau khotbah adalah kegiatan bermisi, oleh sebab itu disebut khotbah yang misiologis yaitu penekanan pada bagaimana para pendengar Firman kembali mewujudkan Firman tersebut dalam panggilan profetis umat yang diutus ke dalam dunia.

Khotbah memang telah menjadi inti dalam setiap ibadah, akan tetapi apakah khotbah-khotbah dalam jemaat sudah dilihat atau dipahami oleh gereja dan warga jemaat sebagai kegiatan misiologis? Gereja mesti bermisi juga melalui khotbah atau pemberitaan Firman yang mendorong tindakan kesaksian! Gereja bukan saja alat misi namun seluruh kehidupan bergereja itu sendiri adalah misi. Jadi tidak ada sedetikpun dan sekelebat ruang pun dari kehidupan bergereja itu lepas dari misi, sebab hakikat gereja itu sendiri adalah misi. Semua gereja dengan demikian menjadi gereja yang missioner. Seluruh bentuk pelayanan gereja, karena hakekat misionalnya, mestinya seluruhnya bermuara pada kegiatan yang sifatnya misional. Sampai pada titik ini yaitu prinsip dan hakikat gereja sebagai misi, Widi Artanto menegaskan, untuk menjadi gereja yang missioner, sebagai titik berangkat gereja mengimplikasikan misi di tengah-tengah dunia. ${ }^{35}$

Di atas telah dikemukakan bahwa salah satu model dan pendekaan misi yang berkembang pada masa ekumenis saat ini adalah misi sebagai dialog profetis yang di dalamnya pewartaan dan kesaksian menjadi dua hal yang tidak dapat dipisahkan. ${ }^{36}$ Model ini berangkat dari model misi Yesus Kristus yang terlihat dalam kitab-kitab sinoptis yaitu dengan berkhotbah keliling sebagaimana Bosch kemukakan sebagai model-model misi dalam Injil Sinopsis. ${ }^{37}$ Berkhotbah keliling yang dilakukan Yesus meliputi pengajaran, peneguhan dan pembebasan dari pemikiran lama mengenai berbagai hal terkait tradisi ke pemahaman baru di dalam Kristus. Selain melakukan khotbah keliling, Yesus juga sekaligus melakonkan firman itu sendiri, ${ }^{38}$ yaitu dengan pelayanan nyata melalui penyembuhan, tindakan-Nya yang merangkul orang-orang kecil dan lemah, melakukan dan mendorong keadilan di tengah masyarakat, dan lain-lain. Khotbah-kotbah Yesus tidak

${ }^{34}$ James S Schrorer and Stephen B Bevans, New Diretion in Mision and Evangelization (Markynol: Orbis Books, 1922).

35 Widi Artanto, Menjadi Gereja yang Misioner, 33.

36 Bevans and Schroeder, Terus Berubah, Tetap Setia, 597.

37 David, Transformasi Misi Kristen:Sejarah Teologi Misi Yang Mengubah Dan Berubah, 87-176.

38 Bevans and Schroeder, Terus Berubah, Tetap Setia, 598. 
berhenti hanya pada tataran verbal tapi dilakukan dan mendorong orang lain yang mendengar, melakukan Firman tersebut. Pola pemberitaan Injil Yesus inilah yang penulis hendak tekankan dalam tulisan ini sebagai dasar untuk melakukan khotbah yang berwawasan misiologis.

Khotbah sebagai salah satu pendekatan misi yang strategis karena letaknya sebagai pusat dalam tata ibadah gereja, seyogianya menjadi perhatian gereja, agar khotbah-khotbah tersebut berwawasan misiologis. Artinya khotbah-khotbah tersebut dapat mengantar setiap orang untuk secara sadar bahwa secara inheren di dalam dirinya ada tugas sebagai missio personae. Sebagaimana kita ketahui Allah adalah pemilik misi yang agung (misio Dei), agar manusia diselamatkan dari dosa dan kematian kekal. Untuk itu Allah mengutus diri-Nya dalam Yesus Kristus (missio Christiae), selanjutnya mengutus umat percaya yang diselamatkan yaitu gereja (missio ecclesiae) dan di dalam umat percaya tersebut terdapat pribadi-pribadi yang diutus (missio personae) ke dalam rumah tangga masing-masing (mission domestica) dan ke dalam kehidupan sehari-hari untuk menjadikan dunia sebgai panggung kemuliaan Allah (Gloria Teatrhron Deo). ${ }^{39}$

Terdapat tanggungjawab pribadi sebagai gereja untuk memberitakan Injil, sebagaimana kesadaran Paulus ketika dia mengatakan, "Celakalah aku jika aku tidak memberitakan Injil" (I Kor.9;16). Paulus hendak mengatakan bahwa letak penting missio personae, sehingga ia merasa celaka jika tidak memberitakan Injil adalah karena setiap umat Tuhan tidak hanya dipanggil untuk percaya dan diselamatkan, tetapi dipanggil untuk memberiakan Injil, sebagaimana pola pemberitaan Injil yang

dimodelkan oleh Yesus Kristus dalam pelayanan bersama dengan murid-murid.40

Menjadi jelas bahwa gereja harus melakukan misi sebagai hakekatnya (Mat.28:1820; Mark. 16:15). Bagaimana tugas perutusan itu dilakukan, Lukas mengungkapkannya secara lugas sebagaimana kutipan di bawah ini"

"Roh Tuhan ada pada-Ku, oleh sebab Ia telah mengurapi Aku, untuk menyampaikan kabar baik kepada orang-orang miskin; dan Ia telah mengutus Aku untuk memberitakan pembebasan kepada orang-orang tawanan, dan penglihatan bagi orang-orang buta, untuk membebaskan orang-orang yang tertindas, untuk memberitakan tahun rahmat Tuhan telah datang."(Lukas 4:18-19)

Sebagaimana dikemukakan di atas, bahwa khotbah adalah bagian dari penginjilan atau pemberitaan Firman yang dalam bingkai lebih luas merupakan bagian dari misi gereja, maka perlu dikemukakan khotbah misiologis yang dimaksud. Pengkhotbah sebagai utusan untuk memberitakan Injil, harus dapat melahirkan perutusan baru yang percaya siapa yang diutus Allah, Dialah yang menyampaikan firmanAllah, karena Allah mengaruniakan Roh-Nya dengan tidak terbatas". Semua hal ini dapat dilakukan jika dan mengenal Allah yang Maha Kasih dan sadar akan tugas yang Allah berikan melalui Firman yang didengar melalui khotbah. Inilah yang penulis sebut sebagai khotbah yang berwawasan misiologis. Yohanes 3:34 menegaskan, "Sebab khotbah-khotbah kita memperhatikan unsur-unsur perutusan tersebut sebagai tujuan khotbah. Khotbah yang

\footnotetext{
39 Widi Artanto, Menjadi Gereja yang Misioner, 65-67.

40 Bevans and Schroeder, Terus Berubah, Tetap Setia, 504, 580, 597, 599.
} 
berwawasan misiologis, sejatinya adalah khotbah yang menggerakkan orang sadar bahwa dirinya adalah umat yang percaya dan diselamatkan menjadi missio personae dalam bingkai besar missio Dei.

Bagi Calvin, pemberitaan Firman tidak berhenti pada saat khotbah-khotbah itu selesai dilaksanakan di atas mimbar, tetapi seyogianya berlanjut pada kehidupan nyata sebagai ibadah yang sejati. ${ }^{41}$ Khotbah semestinya dapat membuat setiap orang yang mendengar khotbah menjadi utusan Kristus untuk kembali memberitakan karya dan kasih Allah serta kehendak Allah bagi umat percaya. Khotbah pada galibnya berwawasan misiologis yang berimplikasi pada umat yang tergerak sebagai utusan Allah sebagai pelaku-pelaku Firman di mana anggota jemaat atau pendengar diutus. Ketika hal ini terjadi, maka menurut penulis, imajinasi Calvin mengenai "teathron gloria deo", dunia menjadi panggung kemuliaan Allah akan menjadi implikasi yang menubuh dalam kehidupan umat.

Khotbah yang berwawasan misiologis menjadi wahana bagi pertumbuhan iman jemaat dan selanjutnya menjadi kesaksian. Persekutuan jemaat mula-mula dalam Kisah Para Rasul mempelihatkan sebuah model kehidupan jemaat yang bertumbuh, dan pertumbuhan itu terlihat, baik secara kualitas hidup maupun kuantitas. Model dan cara hidup mereka memperlihatkan kehidupan yang misional seperti yang dikemukakan oleh Adi Putra dalam menelisik hakikat pertumbuhan gereja berdasarkan Kisah Para Rasul 2:41-47.42 Dalam artikelnya itu, Putra menegaskan bahwa pertumbuhan gereja seyogianya menjadi tujuan dari pemberitaan firman. Terkait dengan hal itu, penulis menegasikan salah satu model yang menjadi inti persekutuan jemaat mula-mula yaitu bertekun dalam pengajaran para Rasul, sebagai prinsip dasar sebuah khotbah yang berwawasan misiologis. Pengajaran yang dimaksud adalah pemberitaan Firman yang sangat berkuasa mengarahkan umat untuk tidak sekedar menyenangkan telinga dengan khotbah-khotbah yang kurang menekankan unsur-unsur pengutusan, pengajaran dan penyadaran, tetapi lebih pada bagaimana umat dituntun untuk melakukan firman tersebut sebagai tindakan misiologis dari khotbah yang berwawasan misiologis. Ayat 40 mengatakan, "Dan dengan banyak perkataan lain lagi ia memberi suatu kesaksian yang sungguh-sungguh dan ia mengecam dan menasihati mereka katanya: "Berilah dirimu diselamatkan dari angkatan yang jahat ini!" Bukti bahwa khotbah atau pengajaran yang sungguh-sungguh tersebut merupakan kuasa dari khotbah yang berwawasan misiologis adalah jemaat memberi diri untuk dibaptis dan jumlah mereka bertambah. Selanjutnya ayat 44 mengatakan, "Dan semua orang yang telah menjadi percaya tetap bersatu, dan segala kepunyaan mereka adalah kepunyaan bersama, dan selalu ada dari mereka yang menjual harta miliknya, lalu membagi-bagikannya kepada semua orang sesuai dengan keperluan masing-masing". Kisah jemaat mula-mula yang mendengar dan digerakkan

${ }^{41}$ Bili Kristianto, "Calvin and the Potential of His Thought for Christian Worship" Veritas: Jurnal Teologi dan Pelayanan 19, No. 2 (Mei 2020): 119-133.

42 Adi Putra, "Hakikat Pertumbuhan Gereja Berdasarkan Kisah Para Rasul 2:41-47," BIA': Jurnal Teologi dan Pendidikan Kristen Kontekstual 3, No.2 (2020): 261-281. 
oleh khotbah yang berwawasan misiologi itu diakhiri dengan closing statment yang kuat, “...Dan mereka disukai semua orang. Dan tiap-tiap hari Tuhan menambah jumlah mereka dengan orang yang diselamatkan". Tanpa mengelaborasi lebih jauh teks tersebut, menjadi jelas bahwa dampak pengajaran Rasul yang kemudian penulis sebut sebagai pengajaran atau khotbah yang berwawasan misiologis ialah pertumbuhan jemaat dengan indikator kualitas hidup yaitu saling memperhatikan, menjadi bagian yang penting dari yang lainnya, mereka disukai semua orang. Kesaksian hidup dari umat yang bertekun dalam pengajaran atau khotbah yang berwawasan misiologis tersebut ialah mereka disukai semua orang sehingga jumlah mereka semakin bertambah. Jadi terlihat pola yang jelas yaitu khotbah yang berwawasan misiologis -melahirkan sikap hidup misional - menjadi kesaksian buat orang lain - bertambah jumlah. Jadi jumlah atau kuantitas adalah akibat langsung dari gaya hidup misional atas khotbah yang berwawasan misiologis.

\section{Kesimpulan}

Penelitian ini memperlihatkan bahwa pemberitaan Injil melalui khotbah adalah bagian dari misi gereja dan gereja-gereja perlu untuk mengembangkan khotbah yang berwawasan misiologis dalam rangka pertumbuhan iman jemaat. Uraian deskriptif dalam penelitian ini dapat membantu gereja memahami lebih jauh misinya melalui pemberitaan Injil dalam bentuk khotbah atau berkhotbah. Hal ini sekaligus menjadi titik berangkat evaluatif terhadap khotbah-khotbah gereja masa kini menuju khotbah yang berwawasan misiologis. Khotbah yang berwawasan misiologis adalah khotbah yang dapat mengarahkan dan menggerakkan seluruh elemen jemaat untuk terlibat dalam pelaksanaan misi Allah sebagai dampak dari khotbah-khotbah tersebut.

Penelitian ini juga mengemukakan pendasaran teologis khotbah yang disebut berwawasan misiologis. Pendasaran teologis pemahaman misiologis dapat ditemukan dalam pandangan para pakar khususnya misiolog seperti Kuyper, Bosch, Bevans, Edmun Woga, dan Widi Artanto, yang dikemukakan pendapat dan pemahamannya dalam penelitian ini. Calvin sendiri menempatkan pemberitaan Firman sebagai yang utama dalam ibadah. Para pakar tersebut memberi pendasaran teologis tentang pemberitaan Firman yang sekaligus merupakan deklarasi misilogis bahwa khotbah merupakan kegiatan misi, sehingga khotbah-khotbah Kristiani selayaknya dipersiapkan secara bersengaja menjadi khotbah-khotbah yang berwawasan misiologi.

Kuiper mengatakan, "pemberitaan Injil sebgai bagian dari misi gereja adalah bagian dari Misi Allah (misio Dei) yang mengutus Kristus (misio Christiae) yang kemudian bermuara pada misi gereja (misio ecclesiae) sebagai keseluruhan pekerjaan Allah untuk menyelamatkan dunia; mulai dari pemilihan Israel, pengutusan nabi kepada Israel dan kepada bangsa-bangsa sekitarnya, pengutusan Kristus kepada dunia, pengutusan rasulrasul dan pekabar-pekabar Injil kepada bangsa-bangsa. Bagi Bosch pendasaran lain yang muncul pada dekade akhir sebagai paradigm misi ekumenis ialah paradigm misi yang 
mulai meletakkan kembali pemahaman gereja sebagai alat atau utusan yang tujuannya atau objeknya adalah dunia dan itu dapat dilakukan dalam pemberitaan dan kesaksian hidup (Kisah Para Rasul 2:1-47). Sementara itu, Stevens Bevans dan Roger Schroeder menekankan bahwa misi sebagai pewartaan dapat menolong gereja bertumbuh lalu kemudian mewujudkan keutuhan ciptaan, kemajemukan/pluralitas, misi sebagai pembebasan seluruh umat, misi sebagai dialog profetis, serta yang memperdulikan perempuan dan kaum disabilitas. Semua itu dapat berangkat dari pemahaman misi yang menyeluruh, misi pewartaan tentang Yesus Kristus sebagai pembebas dan juruselamt universal (Lukas 4:18019).

Penelitian ini dapat menjadi masukan bagi gereja-gereja untuk melihat betapa pentingnya pemberitaan Firman atau khotbah, sebagai bagian integral dari misi dalam mewujudkan tanggungjawab pemberitaan Injil Kristus. Atas dasar itu, maka gereja mestinya mempersiapkan khotbah dengan lebih baik lagi, yang menekankan unsur pengutusan, pengajaran dan penyadaran yang penulis sebut sebagai khotbah yang berwawasan misiologis.

\section{Referensi}

Applegate, Mark. "Differences Between Non-Denominational \& Baptist Churches." Biz Fluent, Agustus 2018. https://bizfluent.com/12083238/differences-betweennon-denominational-baptist-churches.

Asrilita, Tiara. "Pengaruh Pengkhotbah Tamu Dalam Pertumbuhan Iman Di JKI Imanuel Kudus.” 2019.

Atje, Gerry. "Pemberitaan Firman Di Jemaat.” Survey presented at the Survey, Jakarta, 2007.

Bawengan, Glorius. Komet: Khobtah Multikreatif, 2018.

Bevans, Stephen B, and Roger P Schroeder. Terus Berubah Tetap Setia: Dasar, Pola, Konteks Misi. Ledalero, 2006.

Cemerlang, Yosua Felciano, and Hengki Wijaya. "Misi Dan Kebangkitan Rohani: Implikasi Misi Allah Bagi Gereja." Jurnal Ilmiah Religiosity Entity Humanity (JIREH) 1 No.1 (June 2019): 57-71.

David, J. Bosch. Transformasi Misi Kristen:Sejarah Teologi Misi Yang Mengubah Dan Berubah. 11th ed. Jakarta: BPK Gunung Mulia, n.d.

Epan, Yovianus, and Paulus Purwato. "Metode Pemberitaan Kabar Baik Tuhan Yesus Dalam Matius 4:23-25 Dan Aplikasinya Bagi Pemberitaan Kabar Baik,." Miktab: Jurnal Teologi dan Pelayanan Kristiani 1 No.1 (June 2021): 1-27.

Frans, Wijsen. Metode-Metode Penelitian Misiologis Frans Wijsen. Peter Lang, Bern, 2013.

Gea, Ibelala. "Beritakan Injil Kepada Segala Makhluk." BIA': Jurnal Teologi dan Pendidikan Kristen Kontekstual 1, no. 1 (June 30, 2018): 56-69. 
Jonge, Christian de. Apa Itu Calvinisme? BPK Gunung Mulia, 2000.

Kuiper, Arie de. Missiologia. 18. BPK Gunung Mulia, 2010.

Mersi Bombongan, Rantesalu, and suswati Duapadang. "Analisis Tentang Pengaruh Khotbah Bagi Pertumbuhan Gereja Masa Kini." Integritas:Jurnal Teologi 3, Nomor 1 (June 2021): 240-255.

Paas, Stevan. "A Case Study of Church Growth by Church Planting in Germany: Are They Connected?" Sage Journal 42, No. 1. (2018). https://journals.sagepub.com/doi/10.1177/2396939317738896.

Putra, Adi. "Hakikat Pertumbuhan Gereja Berdasarkan Kisah Para Rasul 2:41-47." BIA': Jurnal Teologi dan Pendidikan Kristen Kontekstual 3, No.2 (2020): 261-281.

Santoso, Dwi Setio Budiono. "Peran Khotbah Gembala Sidang Dalam Pertumbuhan Rohani Jemaat." Magnum Opus: Jurnal Teologidan Kepemimpinan Kristen 1 No.2 (June 2020): 88-97.

Santoso, Iskandar. "Khotbah Yang Berkuasa, Suatu Tinjauan Praktis." Aletheia 4 No.6 (March 2002): 43-61.

Schrorer, James S, and Stephen B Bevans. New Diretion in Mision and Evangelization. Markynol: Orbis Books, 1922.

Solihin, Benny. 7 Langkah Menyusun Khotbah Yang Mengubah Kehidupan. SAAT Malang, 2014.

Stevanus, Kalis. "Karya Kristus Sebagai Dasar Penginjilan di Dunia Non-Kristen.” Fidei: Jurnal Teologi Sistematika dan Praktika 3 No.1 (June 2020): 1-19.

Wau, Hansamena. "Hukum Utama Dalam Mempersiapkan Khotbah." Kerusso, Jurnal Teologi dan Pelayanan 6 No.1 (March 2021): 19-34.

Widi Artanto. Menjadi Gereja Misioner dalam Konteks Indonesia. BPK Gunung MuliaKanisius, 1997. 